\title{
http://dx.doi.org/10.4314/ajtcam.v13i1.12 \\ TOGO TO GO: PRODUCTS AND COMPOUNDS DERIVED FROM LOCAL PLANTS FOR THE TREATMENT \\ OF DISEASES ENDEMIC IN SUB-SAHARAN AFRICA
}

\author{
Nassifatou Koko Tittikpina ${ }^{1,4,5}$, Chukwunonso ECC Ejike ${ }^{1,2,3}$, Ethiene Castelluci Estevam ${ }^{1}$, Muhammad Jawad \\ Nasim $^{1}$, Sharoon Griffin ${ }^{1}$, Patrick Chaimbault ${ }^{4}$, Gilbert Kirsch ${ }^{4}$, Wouyo Atakpama ${ }^{5}$, Komlan Batawila ${ }^{5}$ and Claus \\ Jacob $^{1^{*}}$
}

\author{
${ }^{1}$ Bioorganic Chemistry, Department of Pharmacy, University of Saarland, Campus B2 1, D-66123 Saarbruecken, \\ Saarland, Germany, ${ }^{2}$ Department of Biochemistry, Michael Okpara University of Agriculture, Umudike, PMB 7267 \\ Umuahia, Abia State, Nigeria, ${ }^{3}$ Department of Medical Biochemistry, Federal University Ndufu-Alike, PMB 1010 \\ Abakaliki, Ebonyi State, Nigeria, ${ }^{4}$ Laboratoire d'Ingenierie Moleculaire et Biochimie Pharmacologique, EA 3940, FR \\ CNRS 2843, UFR SciFA, Rue du General Delestraint, 57070 Metz, France, ${ }^{5}$ Laboratory of Bootany and Plants \\ Ecology, University of Lomé, Togo \\ "Corresponding author: E-Mail: c.jacob@mx.uni-saarland.de
}

\begin{abstract}
Background: Many African countries suffer from endemic diseases which are often caused by infections and seriously affect the social and economic development of these nations. While the access to proper medication is still limited, many of these countries are, at the same time, rich in medical plants.

Materials and Methods: A review of relevant scientific (and gray) literature was carried out and information obtained from local authorities in medicinal plants. A synthesis of the data obtained was thereafter performed and recommendations for the future proposed.

Results: Plants such as Cissus aralioides, Securidaca longipedunculata, Piliostigma thonningii, Nauclea latifolia, Ocimum gratissimum and Newbouldia laevis are widely reported to be used in the treatment of endemic diseases in Togo and her neighbouring countries.These plants often contain highly potent chemical compounds, such as quinones, xanthones, tannins and terpenes and therefore may provide an alternative avenue to short-term treatment. A combination of further analysis of plant materials and their active ingredients on the one hand, and modern technology to turn such natural products into commercial equivalents on the other, is required in order to identify the targets and modes of action of these natural materials, unlock access to them, and ultimately produce valuable medicines and phytoprotectants based on locally grown plant materials.

Conclusion: The production of plant-derived products, as advocated in this paper, is in line with the WHO's traditional medicine strategy 20142023, and will eventually yield a sustainable health-and-wealth generating cycle that will benefit a countries in the region, economically and ecologically.
\end{abstract}

Keywords: Togo, redox active secondary metabolites, phytochemicals, antimalarial activity, antidiarrheal activity, tropical diseases.

\section{Plants as a widely used natural resource in Togo}

Many sub-Saharan African countries suffer from immense health-related problems, diseases and epidemics, which impact heavily on their populations, and hold back the development of their societies and economies. This issue has recently been highlighted by the outbreak of Ebola, yet there are also many other, equally damaging diseases, including, for instance, malaria, various types of fevers and infections by bacteria and infestations by pathogenic nematodes (Hotez and Kamath, 2009; Crump, 2012). Paradoxically, whilst these countries are a hotbed of infectious diseases, they are also rich in natural resources, and among them a myriad of plants containing biologically active ingredients which seem to be active against many microbes. By unlocking this treasure chest of local "green gold", it should therefore, in theory, eventually be possible to develop affordable medicines locally and to apply them to the populations in need. Since many of these natural products are also active against agricultural pests (Shrivatava et al., 2009) a similar and equally beneficial approach may be possible in the field of "green agriculture" - for instance in protecting crops and treating farm animals. Unfortunately, an effective local pharmaceutical industry dealing with locally relevant illnesses by exploiting locally available (plant) materials is still a long way off. Here, the key to unlocking the potential provided by natural products for medical and agricultural applications clearly is research and product development. In this regard, many sub-Saharan African countries have embarked with considerable enthusiasm on the long road of developing effective and internationally visible research facilities and programs, programs which often focus on agriculture, botany, biochemistry, pharmacy and medicine.

One country in West Africa which in many aspects exemplifies and showcases this drive of "going and doing it local" is the Republic of Togo. We will therefore focus our attention on this country as an example to illustrate how the availability of natural plant products - and a thorough scientific analysis of active ingredients - may ultimately benefit medicine and agriculture, as well as the development of sustainable health-and-wealth generating cycles. It should be borne in mind, of course, that political boundaries are always artificial and that neither plants, nor their traditional uses, nor diseases, are restricted by such divides. Hence most of the issues discussed here equally apply to other countries in the region, such as Cote D'Ivoire, Ghana, Benin or Nigeria.

Togo is a comparably small country of currently just above 6 million inhabitants (51.4\% women, $48.6 \%$ men) and a size of $56.8 \mathrm{~km}^{2}$ located on the western coast of Africa, between $6^{\circ} 06^{\prime}-11^{\circ} 08^{\prime} \mathrm{N}$ and $0^{\circ} 09^{\prime}-1^{\circ} 49^{\prime} \mathrm{W}$ (Fig.1). Geographically, and also considering the specific vegetation present, it belongs to the Guinean forest-savanna mosaic, which encompasses a region stretching from western Senegal to eastern 


\section{http://dx.doi.org/10.4314/ajtcam.v13i1.12}

Nigeria, and including countries such as Cote D'Ivoire, Ghana, Burkina Faso and Benin (White, 1986). This region is particularly fertile and, as will be shown in this review, harbors many botanically and pharmaceutically interesting plant species which can be used for a variety of purposes. In the northern part of the country (north of the $8^{\text {th }}$ Parallel), the climate is Sudanese type with one raining season and one dry season. In the southern part, a subequatorial or Guinea climate prevails, and the rainy season (which ordinarily begins in March and ends in October) is broken for a short period in August, called the 'August break'. This diverse climate gives rise to highly diverse vegetation (Ern, 1979). From the perspective of natural products, it includes rainforests as well as wooded savannahs, grass-lands, agroforestry parklands, and even a mountainous zone with dense dry forests. Ultimately, Togo is therefore blessed with a lush and, at the same time, diverse vegetation which grows around the year and, if used properly, may provide the basis for sustainable production of plants and plant-derived materials and products.

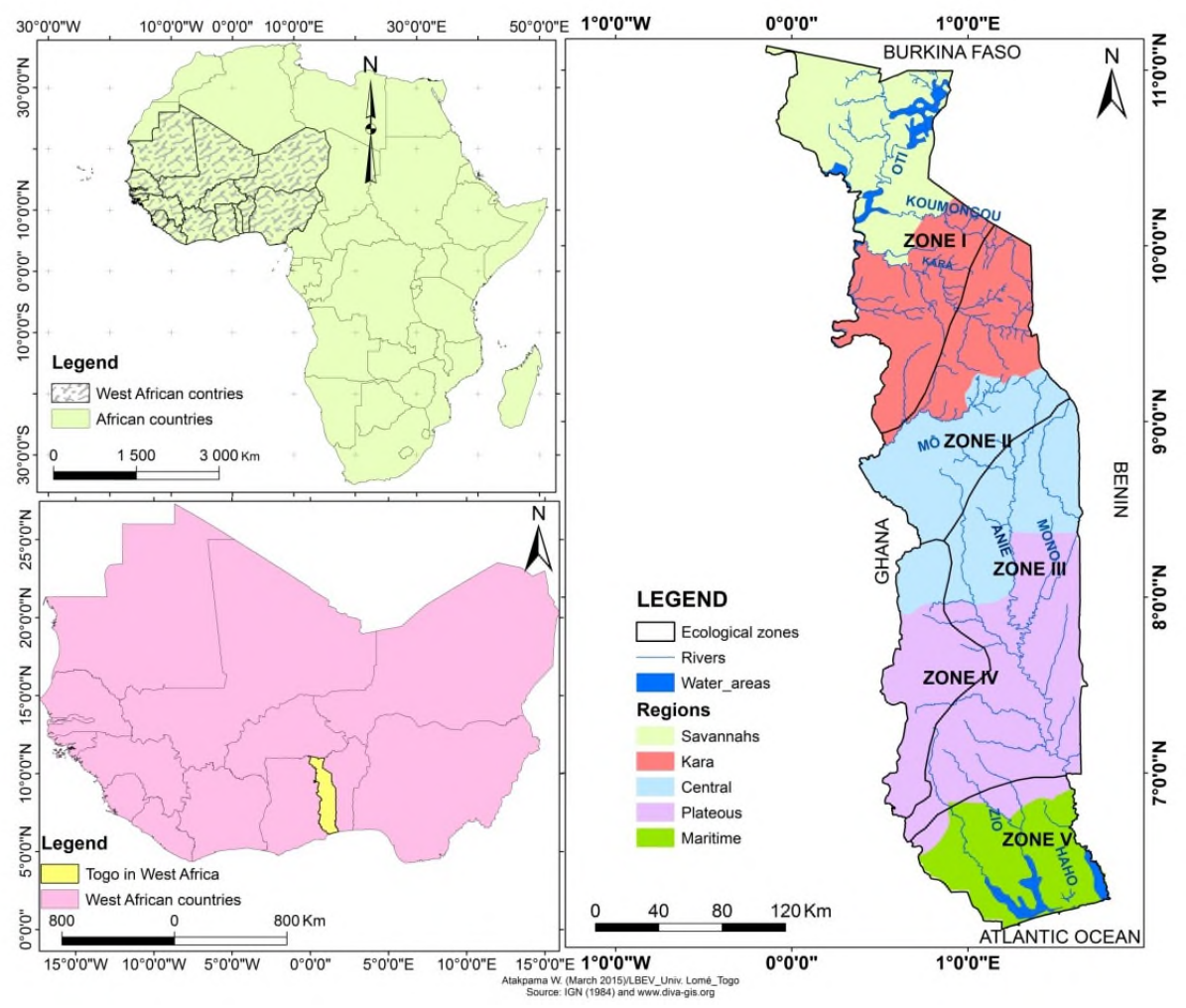

Figure 1: The location of the Republic of Togo at the center of the Guinean forest-savanna mosaic in sub-Saharan Western Africa.

Today, the Togolese use this rich vegetation for a variety of different purposes, ranging from foodstuff for humans and animal feed, to fertilization in agriculture, ethnic rituals, raw materials for paints, and also as materials in traditional medicine. In fact, Tchacondo et al. (2011) report that $80 \%$ of the population rely on medicines from plants for their primary healthcare needs. This is hardly surprising given the high cost of orthodox medicines (Cameron et al., 2009), coupled with the fact that almost two-thirds of the population live in rural areas, and the country consists of 42 different ethnic groups, each with its very own traditions and rituals (Kuevi, 1981; Goeh-Akue and Gayibor, 2010). The extensive use of such plants - and products derived from them - in the treatment of various diseases has also resulted in different scientific studies, which have explored the diversity in the use of plants in Togo in general, and the regional folk medicine in particular (Agody, 2007; Moukaila, 2010; Tchacondo et al., 2011; Amegan, 2012; Tittikpina et al., 2013; Franck, 2014; Zabouh, 2014; Sema, 2015; Lawson-Viviti, 2015).

Certain plants, such as the barwood Pterocarpus erinaceus Poir, which will be discussed in more detail later on, are rich in colorful compounds and hence are used traditionally as a source of dyes, for instance to produce paints for local, traditional artists. From a pharmaceutical point of view, such plants at first may appear of limited interest, yet dyes generally interact strongly with organic materials, and such interactions ultimately may also result in a specific biological activity, as seen, for instance, with the dye hydroxyphthalocyanine, which is also effective in the treatment of some cancers (Hu et al., 1998). Other plants such as the papaya, Carica papaya L. (called borofoudé in Kotokoli, adoubatsi in Ewe and debletsi in Ouatchi), the violet tree Securidaca longipedunculata Fresen. (called fozi in Kotokoli, and tritsu in Ouatchi, Ewe and Guin) and Newbouldia laevis (P. Beauv Seeman ex Bureau) (called kpatima in Ewe, Guin and Ouatchi) are believed to possess magic properties and hence are used in traditional rituals (Guenoukpati, 1994; Agody, 2007; Gunn, 2011; Tchakondo, 2012) (Table 1). The leaves of Newbouldia laevis, for instance, are used in the New Year ceremony in the Guin ethnic group of the southern part of the country to cover the sacred stone, whose subsequent colour is believed by the locals to provide an overall feeling of the year to come. Other plants are even more magical, and Byrsocarpus coccinneus Thonn. Ex Schumach (Connaraceae), Vernonia cinerea (L.) LESS (Asteraceae), Scoparia dulcis L. (Scrophulariaceae) and Sida linifolia Juss. ex Cav. (Malvaceae), for instance, are (each) associated with four or even more magic properties.

Yet whilst some plants are used more or less exclusively for magical purposes, such as personal protection, purification, bewitchment and also relief from bewitchment, there is also evidence that others, such as $N$. laevis and S. longipedunculata are rich in biologically active molecules, such as quinones, xanthones, terpenes and tannins, and, perhaps not surprisingly, have also been used traditionally for less mystical, and more down-to-earth purposes, such as treatment of malaria or against parasitic worms. 


\section{http://dx.doi.org/10.4314/ajtcam.v13i1.12}

Tittikpina et al., Afr J Tradit Complement Altern Med. (2016) 13(1):85-94

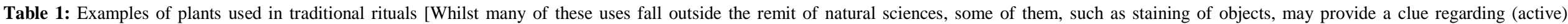
ingredients. As a consequence those plants should not be dismissed outright from a more pharmaceutical perspective.]

\begin{tabular}{|c|c|c|c|c|c|}
\hline Plant & Family & Plant part & Method of use & Purpose & Reference(s) \\
\hline Carica papaya $\mathrm{L}$. & Caricaceae & Roots & Decoction/ powder & Release from spells & Moukaiila, 2011 \\
\hline Capsicum frutescens $\mathrm{L}$ & Solanaceae & Fruits & Crushed & Protection against witchcraft & Gunn, 2011 \\
\hline $\begin{array}{l}\text { Dichrostachys cinerea (L.) Wight } \\
\text { and Am. }\end{array}$ & Fabaceae & Thorns & Ashes & Protection against witchcraft & Tchakondo, et al. 2012 \\
\hline $\begin{array}{l}\text { Gardenia ternifolia Schumach and } \\
\text { Thonn }\end{array}$ & Rubiaceae & Leaves & Infusion & Protection against auto-accidents & Gunn, 2011 \\
\hline Gynandropsis gynandra & Capparidaceae & Leaves & Juice & Release from spells & Gunn, 2011 \\
\hline Leptadenia hastata (Pers.) Decne. & Asclepiadaceae & Entire plant & Infusion & Protection against witchcraft & Agody, 2007, Gunn, 2011 \\
\hline $\begin{array}{l}\text { Newbouldia laevis (P. Beauv } \\
\text { Seeman ex Bureau). }\end{array}$ & Bignoniaceae & Entire plant & Decoction & Release from spells, Purification & Gunn, 2011 \\
\hline $\begin{array}{l}\text { Piliostigma thonningii } \\
\text { (Schumach.) Milne-Redh. }\end{array}$ & Phyllantaceae & Roots & Powder decoction & Release from spells & Tchakondo, et al. 2012 \\
\hline $\begin{array}{l}\text { Securidaca longepedonculata } \\
\text { Fresen. }\end{array}$ & Polygalaceae & Roots & Decoction & Repelling evil spirits & Gunn, 2011 \\
\hline Spermacoce stachydea DC. & Rubiaceae & Seed coat & Decoction & Repelling evil spirits & Tchakondo, et al. 2012 \\
\hline $\begin{array}{l}\text { Xeroderris stuhlmannii (Taub.) } \\
\text { Mendoça and E. P. }\end{array}$ & Fabaceae & Seeds, bark & Decoction & Protection against witchcraft & Tchakondo, et al. 2012 \\
\hline
\end{tabular}

Table 2: Plants used in traditional medicine to treat various highly prevalent infections and infestations affecting the local population, such as malaria, intestinal parasites and dysentery/diarrhea [It should be noted that some of the plants seem to possess more than one "activity", which indeed may be due to the presence of rather reactive compounds with already known biological action.]

\begin{tabular}{|c|c|c|c|c|c|c|}
\hline Plant name & Family & Local name & Part Used & Method used & Disease treated & Reference(s) \\
\hline Nauclea latifolia $\mathrm{Sm}$. & Rubiaceae & Nyimon in $\mathrm{Ou}$ & Arial parts & Decoction & Malaria, Intestinal parasites & Guenoukpati, 1994; Agody, 2007 \\
\hline $\begin{array}{l}\text { Newbouldia laevis (P. Beauv } \\
\text { Seeman ex Bureau). }\end{array}$ & Bignoniaceae & $\begin{array}{l}\text { Kpatima in Ewe; Guin and } \\
\text { Ouatchi }\end{array}$ & Leaves /stems & Decoction & $\begin{array}{l}\text { Malaria, Intestinal parasites, } \\
\text { Dysentery/Diarrhoea }\end{array}$ & Guenoukpati, 1994; Gunn, 2011 \\
\hline Ocimum gratissimum $\mathrm{L}$. & Lamiaceae & $\begin{array}{l}\text { Kounozorou in Kotokoli, } \\
\text { Dzogbetsi in Ou }\end{array}$ & Leaves & Juice/ash & $\begin{array}{l}\text { Malaria, Intestinal parasites, } \\
\text { Dysentery/Diarrhoea }\end{array}$ & $\begin{array}{l}\text { Tchakondo et al., 2012; Moukaïla, } \\
2011\end{array}$ \\
\hline $\begin{array}{l}\text { Piliostigma thonningii } \\
\text { (Schumach.) Milne-Redh. }\end{array}$ & Phyllantaceae & $\begin{array}{l}\text { Klotsi in Ouatchi, Baco in } \\
\text { Kotokoli and Eklon in Ewe }\end{array}$ & Leaves/roots & Infusion/ powder & $\begin{array}{l}\text { Malaria, Intestinal parasites, } \\
\text { Dysentery/Diarrhoea }\end{array}$ & Agody, 2007 \\
\hline $\begin{array}{l}\text { Securidata } \\
\text { longepedonculata Fresen. }\end{array}$ & Polygalaceae & $\begin{array}{l}\text { Fozi in Kotokoli, Tritsu in } \\
\text { Ouatchi, Ewe and Guin }\end{array}$ & Roots/leaves & Powder/decoction & $\begin{array}{l}\text { Malaria, Intestinal parasites, } \\
\text { Dysentery/Diarrhoea }\end{array}$ & Tchakondo et al., 2012; \\
\hline $\begin{array}{l}\text { Cissus aralioides (Baker) } \\
\text { Planch. }\end{array}$ & Vitaceae & Bodi in Kotokoli & Roots & Powder decoction & Malaria, intestinal parasites & Tchakondo et al., 2012 \\
\hline
\end{tabular}


http://dx.doi.org/10.4314/ajtcam.v13i1.12

From traditional uses in Folk Medicine to biologically active molecules

Indeed, when glancing over the long list of plants native to Togo, and their various local uses, one finds several promising leads for the potential treatment of the kind of locally prevalent diseases mentioned above (Fousseni et al., 2014). Malaria, for instance, represents a major disease of epidemic proportions. It kills millions of people in Africa each year, despite the fact that its cause, the Plasmodium falciparum, is a micro-organism that could be treated by adequate antimicrobial agents (see below). Similarly, there are many illnesses caused by poor sanitation and contaminated water, such as diarrhea, dysentery and typhoid fever. Traditional medicine practitioners in Togo (and elsewhere) has developed various "suspect(ed) treatments" for many of these diseases, including non-disease incidents such as scorpion, snake, dog and squirrel bites. Indeed, the use of Xylopia aethiopica Dunal A. Rich. (Annonaceae) fruits or Nicotiana tabacum L. (Solanaceae) leaves against the odd squirrel bite (Agody, 2012) demonstrates that the arsenal available to Folk Medicine in Togo is diverse and can be employed to treat rather specific disorders.

Yet at the same time, few plants have been studied systematically with regard to their biological activities, their active ingredients, modes of action, and toxicological effects associated with them. Whilst there is an emerging body of literature, often authored by colleagues at the University of Lomé, and other universities in the region, access to these studies at the national and international level is limited (e.g. M.Sc. and $\mathrm{PhD}$ theses not published online, texts published in local journals and/or in French etc.). It is therefore expedient to take stock of the existing body of knowledge and to explore new avenues to convert traditional knowledge - and products - into modern science and sophisticated applications using state-of-the-art technology.

Since many diseases caused by bacteria and fungi, such as diarrhoea, dysentery and diverse skin and eye infections can be prevented by an increased hygiene or, at least in theory, could be treated by basic antibiotics (some of which are already available in Togo), we will focus on a few selected diseases which (a) are significant in Togo, (b) have been treated in the past using traditional, plant-based medicines, and (c) for whatever reasons cannot be treated readily with modern drugs at the moment, especially in remote areas. We will also focus on plants that have a known "redox connection", i.e. contain redox active, biologically active compounds. The latter criterion is of particular benefit since many of the pathogenic microbes responsible for human infections are redox sensitive (Antelmann and Helmann, 2011; Peng et al., 2011) and redox modulation in these days is at the forefront of innovative (antimicrobial) drug development based on secondary metabolites of plants and fungi. Indeed, many bacteria and fungi, but especially plasmodia and nematodes, are redox sensitive (Mecklenburg et al. 2009). Hence malaria and various infections/infestations by pathogenic (intestinal) parasites, such as nematodes, may become interesting targets of new redox active secondary metabolites (see below).
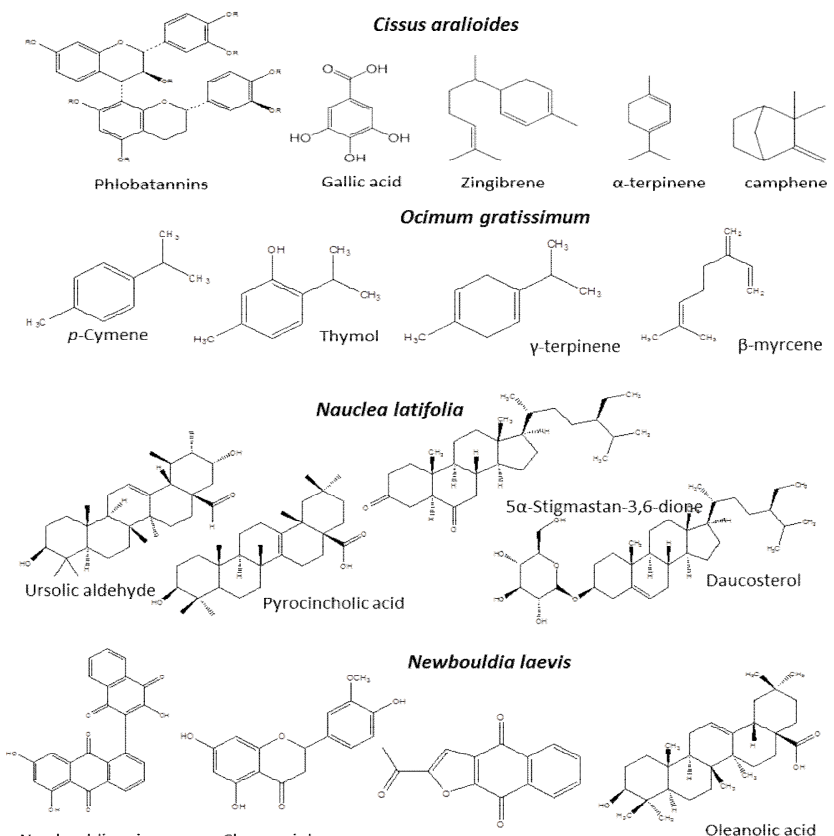

Newbouldia laevis

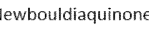

Chrysoerio
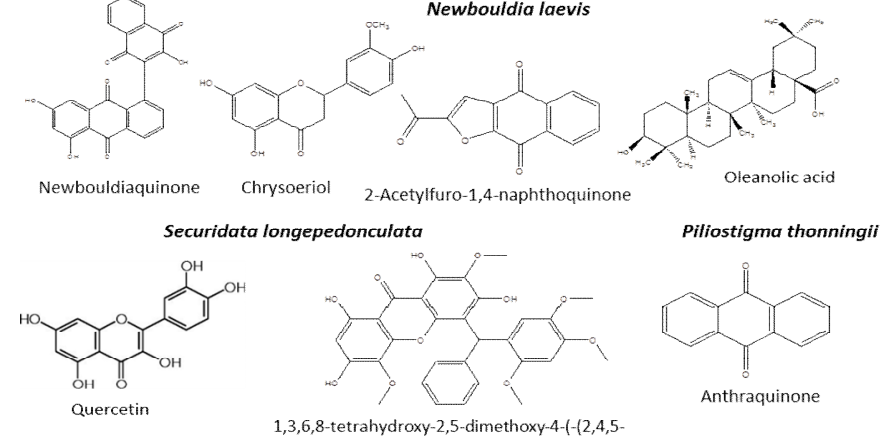

1,3,6,8-tetrahydroxy-2,5-dimethoxy-4-(-(2,4,5-
trimethoxyphenyl $)-1$-phenyimethyl) $x$ xanthone

Figure 2: Chemical structures of some of the most active secondary metabolites found in plants such as Nauclea latifolia, Newbouldia laevis, Ocimum gratissimum, Piliostigma thonningii, Securidaca longipedunculata and Cissus aralioides

Table 2 provides a short and necessarily incomplete overview of the most commonly used plant materials in the treatment of the most prevalent diseases in Togo, viz: malaria, intestinal parasites and dysentery/diarrhoea. Some of the known "chemistry" behind these plants and their suspected therapeutic actions are illustrated in Figures 2 and 3. Whilst this selection of plants is necessarily focussed and hence incomplete, 


\section{http://dx.doi.org/10.4314/ajtcam.v13i1.12}

it already illustrates a number of important points. First of all, there are many plants used to treat the same disease, i.e. there is a healthy redundancy when it comes to finding the (most) active plant material for a particular disease. Secondly, some plants, such as $C$. aralioides, $S$. longipedunculata, $P$. thonningii and $N$. laevis are also used against two or more diseases. Hence there is a similar redundancy when it comes to potential uses for one particular plant (and the various parts thereof). Thirdly, the compounds identified to date in these plants are chemically and pharmacologically rather interesting. Many of these compounds belong to prominent classes of therapeutically active substances which are used already widely in modern Medicine. And finally, the plants which raise the most interest are also rather common and parts of them eventually could be used as raw materials for the development of locally produced drugs.

Cissus aralioides, for instance, is a perennial climbing shrub with long greenish succulent stems that are covered with irritating hairlike structures. It is a climber liana found predominantly in Tropical Africa. C. aralioides' leaves contain a slightly acrid red sap; its flowers are green or white; while its fruits are mostly red. Its fruits impart on it an ornamental look, and are edible (Rodrigues et al., 2014). This plant is highly abundant, easy to culture and traditionally has been used to treat diseases such as malaria and intestinal parasites. The roots of the tree, which have traditionally been used, contain a range of chemical compounds, including alkaloids, tannins, phlotannins, saponins, steroids, terpenes, flavonoids and cardiac glycosides. The basic chemical structures of some of these compounds are shown in Figure 2. Here, one should bear in mind that few studies have been conducted on this plant so far, and that only the most obvious ingredients have been identified. Still, many of the respective classes of compounds represented here have known biological activities. Whilst alkaloids are used in the field of antibiotics and, similar to the cardiac glycosides, in cardiovascular disorders, flavonoids are often considered as antioxidants (Agati et al., 2012). Tannins, in contrast, interact strongly with many proteins and enzymes and hence frequently exhibit a pronounced (cyto)toxicity, particularly against microbes and smaller organisms (see below). They could be used, for instance, to kill microorganisms in the gastrointestinal tract, where they also inhibit enzymes involved in the digestion of sugars, fats and proteins (Xua et al., 2012). Although tannins are oligomeric molecules which, similar to other polyphenols, hardly cross into the bloodstream, their action on the microflora is also legendary. Hence from the perspective of biological chemistry, there is little magic in the fact that the roots of $C$. aralioides may eventually exhibit some activity against plasmodia and intestinal parasites.

A similar consideration also applies to Newbouldia laevis. N. laevis is the only species of the genus Newbouldia (Bignioniaceae) present in Togo. It grows throughout the tropics and subtropics where it is used as a boundary/hedge tree because of its resilience and ease of propagation by stem cutting. $N$. laevis is perennial and grows into a medium size tree. Its bright pink flowers contain sweet-tasting nectar enjoyed by children, while its young immature leaves are used as culinary vegetable. From a medical perspective, its leaves and stem barks are used widely against malaria, intestinal parasites and dysentery (Table 2). They provide a facet-rich composition of active chemicals, among them various quinones, aldehydes and even lapachol [a compound usually obtained from the bark of the lapacho tree and used to treat a wide array of diseases including malaria, leishmaniasis, schistosomiasis and currently under discussion as a possible anti-cancer agent (Epifano et al., 2014)] Quinones, in particular, are highly aggressive agents able to interfere with the intracellular redox homeostasis in several ways (see below). Such compounds (e.g. doxorubicin, daunorubicin) are often highly cytotoxic and hence also used to treat diseases ranging from the skin disease psoriasis to different forms of cancer.

Anthraquinones are also found in the leaves and roots of the tree Pilistigma thonningii. P. thonningii, also known as Camel's foot, Monkey bread, wild bauhinia or Rhodesian bauhinia, is a dioecious and deciduous flowering tree. It grows throughout tropical Africa and easily colonizes farmlands and fallows. Its bark is rough and longitudinally fissured, its leaves green and leathery, while its flowers are white to pink. It yields heavy crops of pods, which serve as food and feed for both humans and livestock, respectively (Deshi et al., 2014). Products derived from this tree have been used traditionally to treat malaria, intestinal parasites, dysentery, and respiratory diseases (Table 2, Figure 2). Besides anthraquinones, the plant is also rich in alkaloids, glycosides, flavonoids, saponins, steroids and tannins. Not surprising, therefore, the arsenal of secondary metabolites found in this plant should enable a range of possible applications. Since the leaves of the plant may also be used, and not only the roots or stem, wider, more or less sustainable applications may be feasible (for instance, the production of crude phytoprotectants, i.e. locally generated "green" pesticides for a wider use in agriculture against fungi, bacteria and troublesome nematodes).

Besides quinones, terpenes, tannins, flavonoids and a range of other polyphenolic compounds, some of the plants employed in traditional Togolese medicine also contain other substances of interest, such as different xanthone derivatives. Another good example of such plants is Securidaca longipedunculata, also known as the violet tree. This is a medium size tree that grows throughout tropical Africa. Its bark is pale and smooth and its distinctly ornamental sweetly scented flowers change from pink to violet. Its round purplish green fruits become pale straw coloured upon maturation, and have a distinctive single oblong membranous wing. The flower which attracts birds and insects is used extensively in traditional folk medicine across Africa (Mustapha, 2013). The roots of $S$. longipedunculata, for instance, are not only rich in quercetin, but also in 1,3,6,8-tetrahydroxy-2,5-dimethoxy-4-(-(2,4,5-trimethoxyphenyl)-1-phenylmethyl) xanthone and 1,3,6-trihydroxy-4,7dimethoxy-2-(-1(2,4,5-trimethoxyphenyl)-1-phenylmethyl) xanthone, two xanthones which may explain some of the traditional uses, for instance against malaria, intestinal parasites, dysentery and respiratory diseases. Indeed, xanthones exhibit a rather distinct redox behavior and their biological activity, for instance as antioxidants and radical scavengers but also as antimicrobial (antibacterial, antifungal) and anticancer agents has been considered as part of numerous studies (Simoben et al., 2015).

And finally, we find plants such as Ocimum gratissimum L. (Lamiaceae) and Nauclea latifolia SM. (Rubiaceae). O. gratissimum is a herbaceous shrub that is indigenous to the tropics and grows widely in West Africa, especially in the Savannah and coastal areas. It is a multibranched plant with dark green leaves which are rich in essential oils (Prabhu et al., 2009). When heated, the leaves give off a characteristic aroma. As a result, they are used as insect repellants (when added to slow burning fires) and in preparation of soups, teas and infusions. $N$. latifolia is an evergreen straggling shrub that grows all over tropical Africa especially in the humid tropical rainforest zone or in savannah woodlands (Arbonnier, 2002; Karou et al., 2011). N. latifolia's canopy is usually open, while its beautiful white flowers line its terminal spherical crown. The leaves of $O$. gratissimum contain many terpenes, while Nauclea latifolia is rich in chemically diverse phyto-steroids. These plants are also used widely, against malaria, intestinal parasites and other ailments. The compounds found in these plants may or may not exhibit a pronounced biological activity in humans, and their mode(s) of action appear to be more complicated - but not entirely uninterestingly from a pharmaceutical point of view. 
Tittikpina et al., Afr J Tradit Complement Altern Med. (2016) 13(1):85-94

http://dx.doi.org/10.4314/ajtcam.v13i1.12

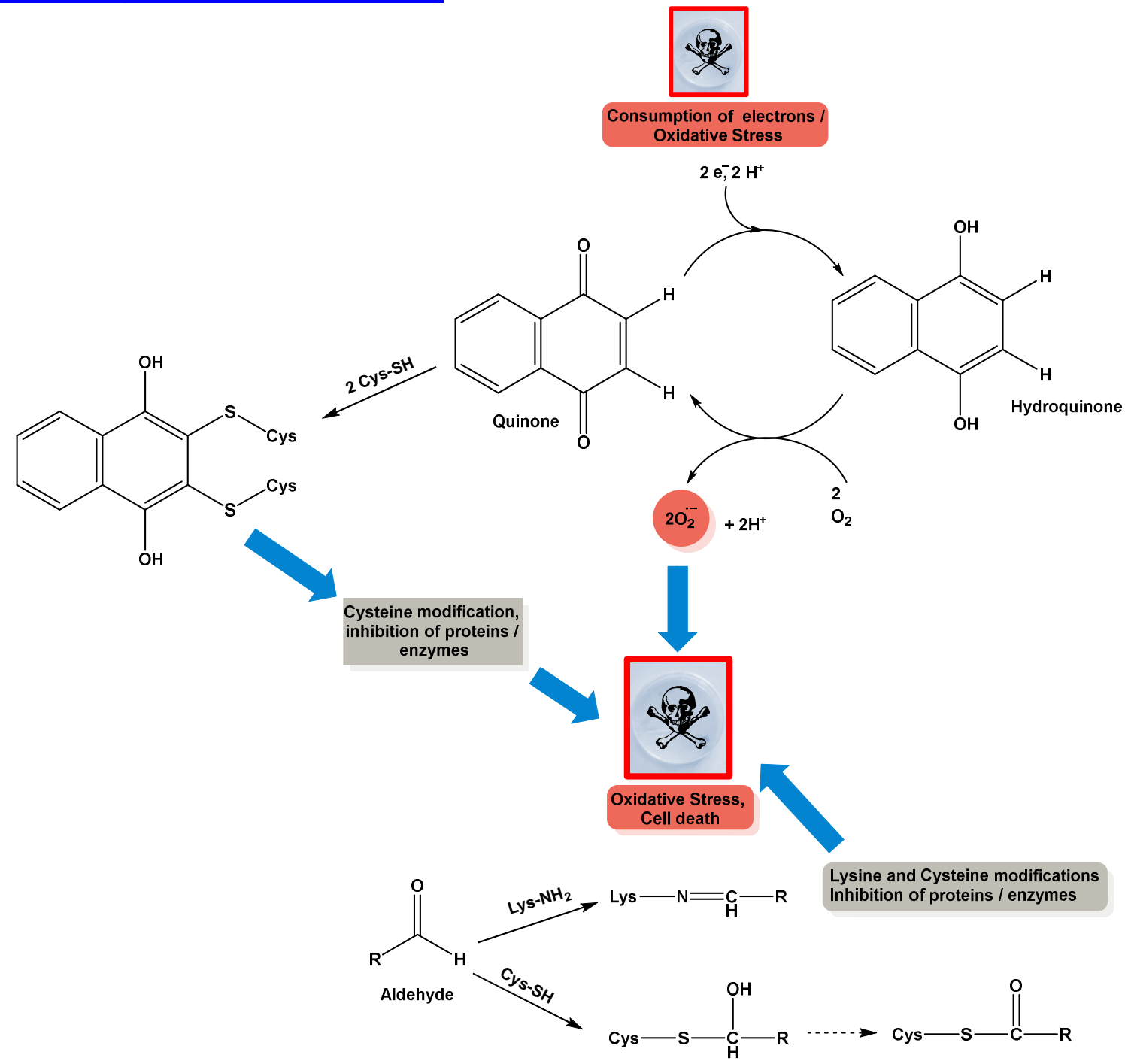

Figure 3: The chemistry behind the mode(s) of action of many redox active secondary metabolites.

[Redox active substances, such as quinones, often are able to modulate the intracellular redox homeostasis, for instance directly by generating Reactive Oxygen Species (ROS) or, more indirectly, by inhibiting antioxidant enzymes or signaling pathways. Others act as reducing agents and radical scavengers. Certain compounds are also strongly electrophilic and able to modify redox sensitive cysteine proteins covalently. Aldehydes, for instance, are reactive yet rare, and they are able to form covalent bonds with lysine residues in proteins. Ologomeric structures, such as tannins, interact non-covalently with many biological molecules, a process which may result in inactivation and denaturation of the molecule affected.]

\section{The biological chemistry of active ingredients}

The presence of many representatives of various well-known classes of chemical compounds in these plants raises the question if it is possible to "explain" the biological activities and traditional medical applications associated with such plant materials. This question is far from trivial as it in many ways connects traditional Togolese/African medicine with modern pharmaceutical science. Not surprisingly, the answer(s) to this question aren't trivial either. First of all, one needs to bear in mind that the compounds isolated and also identified chemically from such plant materials probably only represent the literal tip of the iceberg when it comes to the complex mixture of chemicals found, for instance, in a single leaf of Newbouldia laevis. Even worse, it is often unclear if a specific secondary metabolite acts "alone" or only in concert with other ingredients present in the biological sample. Certain compounds, for instance, rely on the presence of oils and fats for solubility and bioavailability. Secondly, some compounds require others to modulate enzymes involved in xenobiotic transformation in favor of either their conversion to active metabolites or the extension of their half-lives. Furthermore, most of the compounds reported in the literature so far have not been studied for biological activity. Hence little, perhaps next to nothing, is known about the biological activities of such compounds. Surely, some of the compounds found in the plants discussed above, such as quercetin or lapachol, are already better known as they occur widely in other plants as well, and hence have been studied for possible biological activities, yet others are "new". Indeed, the often minute amounts of compounds available after isolation may even prevent a full activity screen. Therefore, a certain analogy with other representatives of the classes of compounds they belong to sometimes provides the first leads. Here, we will briefly attempt to raise interest in certain (classes) of natural compounds because such first leads are promising in the context of the diseases under discussion (i.e. malaria, infections, parasites). 


\section{http://dx.doi.org/10.4314/ajtcam.v13i1.12}

We will necessarily have to focus on a few selected classes of compounds. We believe that redox active and electrophilic molecules such as quinones, xanthones, flavonoids, tannins and also aldehydes are of particular interest and promise, as they often interact with key cellular signaling pathways, such as the ones surrounding the cellular thiolstat (Simoben et al., 2015). Aspects of the chemical reactivity of these molecules which may be (most) relevant in a biological context are illustrated and highlighted in Figure 3 . Needless to say, there are many other, equally interesting groups of compounds, such as the terpenes, fatty acids, glycosides and steroids, yet many of them have been reviewed extensively in the past and the reader's attention is kindly directed towards this literature (Paduch et al., 2007; Kabera et al., 2014).

As mentioned already, quinones are redox active and in the presence of dioxygen and a suitable reducing agent can undergo extensive redox cycling (Figure 3). The latter not only results in the oxidation of the reducing agent consumed, but also in the one- or two-electron reduction of dioxygen, i.e. the formation of the superoxide radical anion $\left(\mathrm{O}_{2}{ }^{*}\right)$ and hydrogen peroxide $\left(\mathrm{H}_{2} \mathrm{O}_{2}\right)$, respectively. These species represent aggressive reactive oxygen species (ROS) which can cause serious damage to cells, and often induce apoptosis via the oxidation of redox sensitive proteins and enzymes and the subsequent activation of one of the pro-apoptotic pathways (Tomasetti, 2015). Depending on the precise chemical structure, quinones are also able to act as electrophiles in Michael addition reactions. This kind of reactivity may damage cellular components, for instance by attaching quinones to cysteine and lysine residues in proteins and enzymes. Depending on the precise redox potential of the quinone, a more beneficial, antioxidant behavior is also possible, as seen, for instance, for the coenzyme $\mathrm{Q}_{10}$ (Lenaz et al., 2007). Hence the presence of specific quinones in plants raises the suspicion that these compounds may act as cytotoxic agents, yet it would be premature to rule out possible antioxidant activities as well.

Similarly, xanthones have long been considered as antioxidants and radical scavengers. Whilst this description certainly holds true in vitro, there is also mounting evidence of a more sinister activity associated with these compounds, such as a pronounced (cyto)toxicity against certain microbes and cancer cells (Simoben et al., 2015). Future studies may examine if this activity is also redox-related or due to an alternative mode of action.

The flavonoids, in contrast, are well known redox active antioxidants, whose activity often relies on the presence of an ortho- or parahydroquinone B-ring. This ring endows the molecules in question with a pronounced redox activity, which initially includes the donation of electrons (Agati et al., 2007). Hence many flavonoids are considered as electron donors, reducing agents and antioxidants, although the hydroquinone/quinone redox chemistry is considerably more complicated (see above). Still, compounds such as quercetin are well-known "antioxidants" and their presence is considered as beneficial in foods and food supplements.

Tannins, in contrast, are oligomeric or even polymeric forms of flavonoids. They are also redox active, and due to their oligomeric structure combine many individual redox centers (e.g. B-rings) in one molecule. In addition, these large molecules are able to participate in extensive hydrogen bond formation. This property enables proanthocyanidins and tannins to interact non-covalently with membranes, proteins, enzymes and even DNA and RNA (Amarowicz, 2007). These interactions are often detrimental for the biomolecule affected, and inactivation and denaturation are frequently the outcome of such interactions. Therefore it is likely that many of those agents show at least some biological activity against lower organisms, such as bacteria, fungi and parasites.

The electrophilic nature of quinones is mirrored in the case of the aldehydes, which are highly reactive and able to interact covalently with many (nucleophilic sites in) biomolecules (Antelmann and Helmann, 2011). They can, for instance, react irreversibly with lysine residues to form imines. The presence of aldehydes in the roots of Newbouldia laevis is therefore revealing. Depending on the exact concentration of these compounds, a rather aggressive chemistry may emerge which surely would be highly damaging to many types of cells and living organisms and ultimately also may contribute to the many biological activities observed already for this particular and particularly interesting plant.

And finally, the terpenes form a specific class of many different compounds, often with dramatically different properties. Some of these agents are also redox active, and whilst their chemistry is often complicated, they frequently exhibit considerable biological activity. Since there are many excellent reviews on this particular class of compounds (Graßmann, 2005; Paduch et al., 2007), we will not dwell on them here any further.

\section{Sustainable product development and ecology: The seven seals of unlocking the treasure chest of Togolese "green gold"}

Initially, it has been our aim to demonstrate the feasibility of "going local", i.e. of developing local therapeutic agents against locally endemic diseases. Clearly, there are many classes of compounds with known biological activities represented in the various shrubs and trees present in Togo. Nonetheless, the presence of such plants, and hence compounds, is only one prerequisite of developing therapeutically active agents. There are additional "keys" required, i.e. conditions to be fulfilled, before a plant such as $N$. laevis or S. longipedunculata can be turned into a successful medication. Besides the availability of sufficient amounts of plants in a given area, the plant also needs to survive the act of harvesting its part(s), hence fruits and leaves are more likely candidates for product development when compared to roots, barks or stems. In fact, agricultural waste, such as skins, shells, seeds of fruits or husks of grain may be the most rewarding sources from an economical and ecological perspective. Indeed, it would be foolish to focus on very rare plants or plants under threat or close to extinction already. And finally, the conversion of these plants into products is the ultimate key required to unlock the treasure chest of "gold". Traditional methods practiced in Togo, such as maceration and extraction using water, alcohol or oils may not be applicable in order to obtain an effective product (Figure 4).

Turning to the analytical methods employed to isolate and subsequently identify such secondary metabolites, extractions using organic solvents, distillation and possibly even nano-milling come to mind. Indeed, the production of crude or refined extracts using solvents such as ethanol, may be an option to generate more reliable ointments, tinctures or creams, bearing in mind that ethanol is widely available even in the absence of chemical suppliers, yet its use is also problematic in many cultures and religions. Still, extraction, distillation and the pressing of oils can provide an initial impetus to develop more sophisticated products. Further refinement may be possible, for instance via purification using different chromatographic methods. This would surely lead to more defined and purer materials with higher concentrations of the active ingredient(s) and probably reduced side effects. Nonetheless, chromatography on a large scale is a method which requires a more advanced technological infrastructure, which may or may not be available yet in countries such as Togo. 
Tittikpina et al., Afr J Tradit Complement Altern Med. (2016) 13(1):85-94

http://dx.doi.org/10.4314/ajtcam.v13i1.12

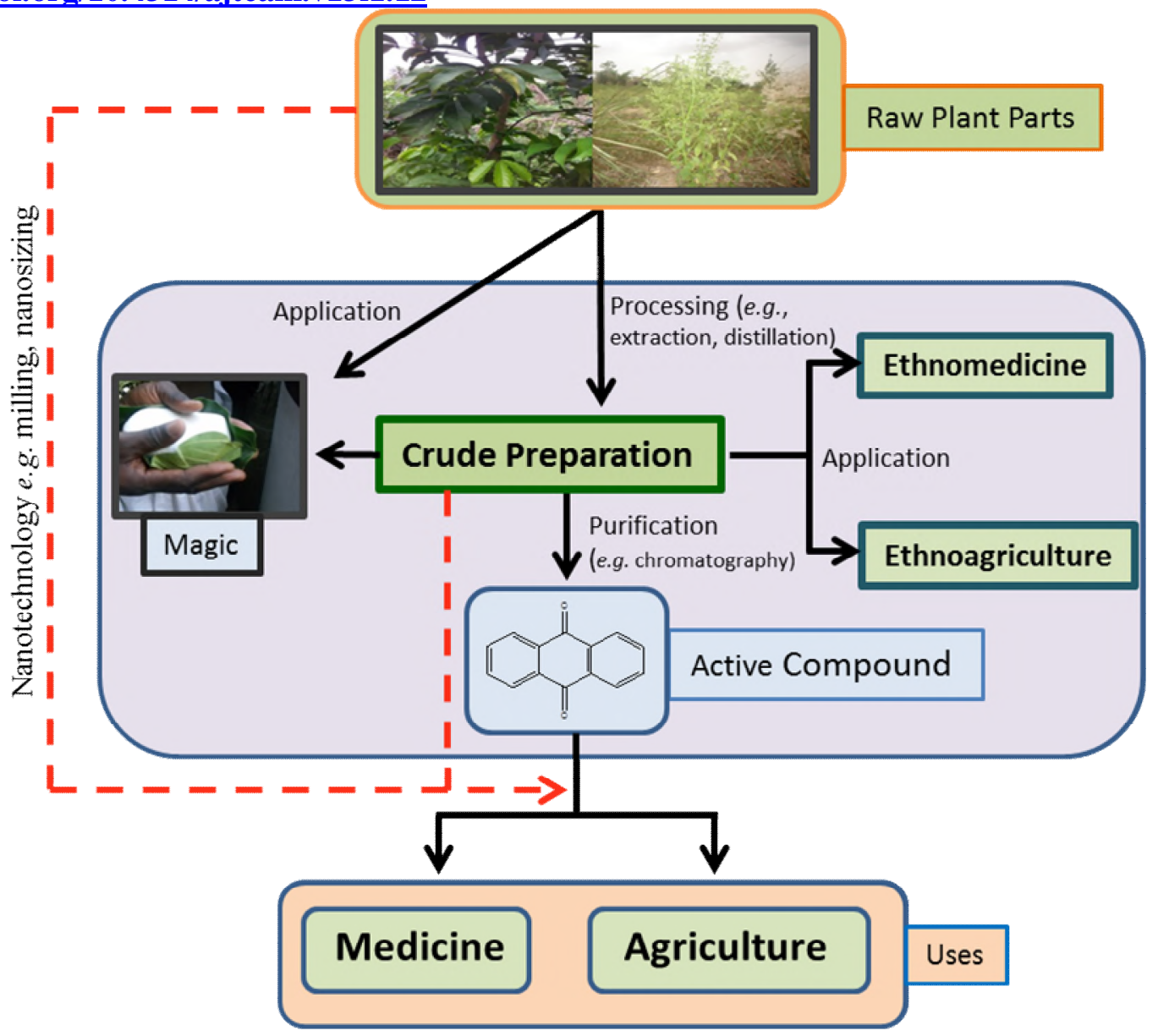

Figure 4: In order to be pharmaceutically active, plant-derived materials need to be bioavailable. [Here, classical methods such as liquid-liquid extraction and distillation slowly give way to more sophisticated methods, including processes derived from nanotechnology, such as milling and spraying.]

It is therefore reasonable to turn the attention to more recent and perhaps daring methods. One of them is nanotechnology. Here, many different methods ranging from dry and wet milling to powder spraying etc. are now routinely available to break down (dry) materials into particles of submicrometer sizes (Jacob et al. 2014; Keck et al., 2014). If prepared properly, such particle suspensions/solutions exhibit good stability, the compounds contained within the particles show improved solubilization properties and hence become bioavailable under physiologically relevant conditions (aqueous media, ambient temperature and $\mathrm{pH}$ etc.). There are already many examples where otherwise hardly soluble natural products have been turned into promising materials using nanotechnology. The natural flavonoid rutin, for instance, has its particular biological, antioxidant activity accentuated when applied in cosmetic preparations in the form of nanoparticles (Keck et al. 2014). Selenium nanoparticles generated by the Lactobacillus sp. are increasingly used in pro-biotic "healthy" drinks (Yazdi et al., 2012; Yazdi et al., 2013). A similar strategy obviously is also available for medical applications, and nanoparticles of pure natural products and mixtures, but also of "milled down" extracts and perhaps even whole plant materials provide a promising alternative to classical strategies. Assuming such technology is available; it would provide an effective, rapid and economical approach towards turning plant materials into applicable products, for instance ointments and crèmes for topical applications.

\section{Conclusions}

Let us therefore return to our initial idea of "going local" and summarize the main arguments collected so far. In the first instance, it has become apparent that even small sub-Saharan African countries, such as Togo, are rich in vastly diverse vegetation which because of the favorable climate in the region grows around the year. Not surprisingly, therefore, many plant products are used by the local population as part of rituals, but also for more mundane uses, for instance to treat squirrel bites and various serious illnesses. Once the "chemistry" contained within the respective plants is analyzed, it becomes apparent that the traditional uses are not entirely - scientifically - unfounded. Indeed, it seems that many of the plants employed traditionally to treat malaria, diverse infections, intestinal and respiratory problems also contain substances which belong to classes of compounds known to exert therapeutic action. In other words, whilst the specific substances found in these plants may not yet have been studied, their "chemotype" promises activity.

Besides the obvious need to investigate such plants and their composites in more detail in the future, the presence of quinones, xanthones, flavonoids, phytosteroids, fatty acids, saponins, glycosides, terpenes, tannins and other polyphenols also bode well for practical applications. Here, the question of turning a given, raw plant material, such as a fruit, leaf, root or bark into a pharmaceutically applicable material becomes important. Among the techniques available to date, it seems that a combination of extraction and nano-sizing may hold the key to finally unlocking many of the - therapeutic - potentials contained within such plants. 


\section{http://dx.doi.org/10.4314/ajtcam.v13i1.12}

Moving on from the more academic discussion, such materials indeed may provide considerable benefits for a number of additional reasons. First of all, the plant materials required are available readily and assuming the plants in question are not damaged or even killed by removing the required parts, such an approach may be sustainable in both regards, economically as well as ecologically. Secondly, the use of drugs based on plants which have formed part of traditional medicine for centuries may also be more acceptable socially, especially among rural communities. Indeed, acceptance of a drug is often an issue, not only among the users, but also in the context of medical licensing. Here as well, agents based on traditional medicine may be more acceptable to the medical community and hence easier to license when compared to synthetic drugs.

And finally, the biological activity seen for many of these plants and products derived from them may not be limited to purely medical applications. Many antimicrobial agents are also effective in the context of agriculture and farming. Some of the preparations may, for instance, be rather useful to treat animals suffering from bacterial, fungal or parasitic infections. Similarly, fungi and nematodes place a considerable burden on the agriculture of West African countries. Assuming that the plant materials needed are widely available, for instance in form of agricultural waste products (e.g. inedible skins, shells, seeds, husk, etc.) or fallen fruits, nuts, leaves etc., a larger scale agricultural application may be possible. In fact, there are various examples which demonstrate the use of refined or processed agricultural products in "green" agriculture as a cheap and safe alternative to the use of costly, often imported pesticides. Such wealth generation cycles not only benefit agriculture, medicine, cosmetics and nutrition, but also the local farming community. It therefore bodes well for an emergent pharmaceutical (and allied) industry and, above all, environmental interdependence, growth and improvement cycles.

Future studies will therefore not only focus on the botanical diversity of Togo, on local and regional medicinal plants and their traditional uses, but increasingly also on the chemistry hidden within those plants, and how to turn such natural into medical and perhaps even commercially viable products. Eventually, a watchful eye and open mind will spot many interesting new leads in plants traditionally used for medical purposes (but also for curing animals, as part of traditional rituals and for the production of dyes) such as Pterocarpus erinaceus Poir, a plant we are currently studying intensively.

\section{Acknowledgments}

The authors would like to thank the following institutions for providing financial support, without which this project would not have been possible: The University of Saarland in Germany; the University of Lorraine in France; the University of Lomé in Togo; The World Academy of Sciences (TWAS) - Deutsche Forschungsgemeinschaft (DFG) Cooperation Visit Fellowship awarded to CECCE and especially the Schlumberger Foundation and its Faculty for the Future stipend to NKT.

\section{References}

1. Agati, G., Azzarello, E. Pollastri, S. and Tattini M. (2012). Flavonoids as antioxidants in plants: Location and functional significance. Plant Sci. 196: $67-76$

2. Agody, K.M. (2007). Contribution au recensement des plantes médicinales au Togo: Cas de la région maritime du Togo. Thèse de Pharmacie, Université Cheick Anta Diop, Dakar, Sénégal. pp 157

3. Amarowicz, R. (2007). Tannins: the new natural antioxidants? Eur. J. Lipid Sci. Technol. 109: 549-551

4. Amegan, K.M.G. (2012). Contribution au recensement des plantes antianémiques: Cas de la région maritime. Th. Doc. Pharmacie, Université de Lomé, Togo. pp 83

5. Antelmann, H. and Helmann, J.D. (2011). Thiol-based redox switches and gene regulation. Antiox. Redox Signal. 14: 1049-1063

6. Arbonnier, M. (2002). Arbres, arbustes et lianes des zones sèches d'Afrique de l'Ouest: CIRAD-MNHN, 573

7. Cameron, A., Ewen, M., Ross-Degnan, D., Ball, D., and Laing, R. (2009). Medicine prices, availability, and affordability in 36 developing and middle-income countries: a secondary analysis. Lancet, 373: 240-249

8. Crump, J.A. (2012). Typhoid fever and the challenge of non-malaria febrile illness in Sub-Saharan Africa. Clin. Infect. Dis. 54:1107-9

9. Deshi, S.N., Wonang, D.L. and Dongs, I.S. (2014). Exploration of Piliostigma Thonningii (Schum.) a tropical tree for possible utilization as a plant-derived pesticide. Acad. J. Interdiscipl. Stud. 3: 108-114

10. Epifano, F., Genovese, S., Fiorito, S., Mathieu, V. and Kiss, R. (2014). Lapachol and its congeners as anticancer agents: a review. Phytochem. Rev. 13:37-49

11. Ern, H. (1979). Die Vegetation Togos. Gliederung, Gefährdung, Erhaltung. Willdenowia pp 295-312.

12. Fousseni, F., Madjouma, K., Dieudonne, G.Y.M., Li, P.D., Hai, Z.X. and Koffi, A. (2014). Global overview of flora and plant diversity in Togo (West Africa). J. Life Sci. Res. 1: 24-30.

13. Franck, E.E. (2014). Importance du temps en pharmacopee traditionelle au Togo. Thèse de Pharmacie Université de Lomé, Togo. pp 61.

14. Goeh-Akue, N.A. and Gayibor, N.L. (2010). Histoires nationales et/ou identités ethniques : un dilemme pour les historiens africains? Paris: L'Harmattan, 309.

15. Graßmann, J. (2005). Terpenoids as plant antioxidant. Vit. Hormones, 72: 505-535

16. Guenoukpati, K. (1994). Contribution au recensement, à l'identification et à la connaissance de quelques espèces végétales utilisées dans la médecine traditionnelle et à la pharmacopée, chez les Ouacthi (République Togolaise). Faculté des Sciences et Techniques, Université Nationale de Côte d'Ivoire. Th Doc, pp 163.

17. Gunn, K.S. (2011). Rites traditionnels et Plantes: Etude ethnobotanique dans la région maritime du Togo. Thèse de Pharmacie, Université Cheick Anta Diop, Dakar, Senegal. pp 66.

18. Hotez, P.J. and Kamath, A. (2009). Neglected tropical diseases in sub-Saharan Africa: Review of their prevalence, distribution, and disease burden. PLoS Negl Trop Dis 3: e412. doi:10.1371/journal.pntd. 0000412

19. Hu, M., Brasseur, N., Yildiz, S.Z., van Lier, J.E., and Leznoff, C.C. (1998). Hydroxyphthalocyanines as potential photodynamic agents for cancer therapy. J. Med. Chem. 41: 1789e802.

20. Jacob, C., Burkholz, T., Kirsch, G., Slusarenko, A. and Winyard, P.G. (2014). Some personal conclusions (Chapter 19). In: C. Jacob, T. Burkholz, G. Kirsch, A. Slusarenko and P.G. Winyard (Eds) Recent advances in redox active plant and microbial products from basic chemistry to widespread applications in medicine and agriculture. Springer, Dordrecht, Holland, pp 471-475 


\section{Tittikpina et al., Afr J Tradit Complement Altern Med. (2016) 13(1):85-94}

http://dx.doi.org/10.4314/ajtcam.v13i1.12

21. Kabera, J.N., Semana, E., Mussa, A.R. and He, X. (2014). Plant secondary metabolites: Biosynthesis, classification, function and pharmacological properties. J. Pharm. Pharmacol. 2: 377-392

22. Karou, S.D., Tchacondo, T., Ilboudo, D.P. and Simpore, J. (2011). Sub-Saharan Rubiaceae: a review of their traditional uses, phytochemistry and biological activities. Pak. J. Biol. Sci. 14:149-169

23. Keck, C.M., Mueller, R.H. and Schaefer, K.H. (2014). Nanotaxis for Antioxidants (Chapter 16). In: C. Jacob, T. Burkholz, G. Kirsch, A. Slusarenko and P.G. Winyard (Eds) Recent advances in redox active plant and microbial products from basic chemistry to widespread applications in medicine and agriculture. Springer, Dordrecht, Holland, pp 471-475

24. Kuevi, D. (1981). Ethnies et langues. Les Atlas Jeune Afrique-Togo, Paris. pp 22-23.

25. Lawson-Viviti, A.F. (2015). Contribution au recensement des plantes utilisées en médecine traditionnelle dans le traitement des maladies cardiovasculaires et du diabète au Togo : Cas de la Région des Plateaux. Lomé (Togo), Université de Lomé. Doc. Pharmacie, pp 66.

26. Lenaz, G., Fato, R., Formiggini, G.F. and Genova, M.L. (2007). The role of Coenzyme Q in mitochondrial electron transport. Mitichondrion, 7: S8-S33

27. Mecklenburg, S., Shaaban, S., Ba, L.A., Burkholz, T., Schneider, T., Diesel, B., Kiemer, A.K., Roseler, A., Becker, K., Reichrath, J., Stark, A., Tilgen, W., Abbas, M., Wessjohann, L.A., Sasse, F. and Jacob, C. (2009). Exploring synthetic avenues for the effective synthesis of seleniumand tellurium-containing multifunctional redox agents. Org. Biomol. Chem. 7: 4753-4762

28. Ministère de l'Agriculture, Togo (2007). Deuxième rapport sur l'état des ressources phytogénetiques pour l'alimentation et l'agriculture au Togo. Togo pp 53.

29. Moukaïla, A. (2011). Plantes alimentaires à usage thérapeutique: Cas de la Région Centrale du Togo. Thèse de Pharmacie, Université de Lomé, Togo. pp 69

30. Mustapha, A.A. (2013). Ethno-medico-botanical uses of Securidaca longepedunculata Fresen (Family-Polygalaceae) from Keffi Local Government, Nasarawa State, Nigeria. J. Nat. Remedies 13: 133-137

31. Paduch, R., Kandefer-Szerszen, M., Trytek, M. and Fiedurek, J. (2007). Terpenes: substances useful in human healthcare. Arch Immunol Ther Exp (Warsz) 5: 315-327.

32. Chen, P.R., Brugarolas, P. and He, C. (2011). Redox Signaling in Human Pathogens. Antiox. Redox Signal. 14: $1107-1118$.

33. Prabhu, K.S., Lobo, R., Shirwaikar, A.A. and Shirwaikar, A. (2009). Ocimum gratissimum: A review of its chemical, pharmacological and ethnomedicinal properties. The Open Complement. Med. J. 1: 1-15

34. Rodrigues, J.G., Lombardi, J.A. and Lovato, M.B. (2014). Phylogeny of Cissus (Vitaceae) focusing on South American species. Taxon 63: 287298

35. Sema, M. (2015). Pratiques traditionnelles et plantes : Etude ethnobotanique dans la préfecture de Doufelgou au Togo. Lomé (Togo), Université de Lomé. Doc. Pharmacie pp 61.

36. Shrivatava, G., Rogers, M., Wszelaki, A., Panthee, D.R. and Chen, F. (2009). Plant Volatiles-based Insect Pest Management in Organic Farming. Crit. Rev. Plant Sci. 29: 123-133

37. Simoben, C.V., Ibezim, A., Ntie-Kang, F., Nwodo, J.N. and Lifongo, L.L. (2015). Exploring cancer therapeutics with natural products from African medicinal plants, Part I: Xanthones, quinones, steroids, coumarins, phenolics and other classes of compounds. Anti-Cancer Agents Med. Chem. 15: DOI: $10.2174 / 1871520615666150113110241$

38. Tchacondo, T., Karou, D.S., Batawila, K., Agban, A., Ouro-Bang'na, K., Anani, K.T., Gbeassor, M. and de Souza, C. (2011).. Herbal remedies and their adverse effects in Tem tribe traditional medicine in Togo. Afr. J. Tradit. Complement. Altern. Med. 8:45-60.

39. Tchacondo, T., Karou, S.D., Agban, A., Bako, M., Batawila, K., Bawa, M.L., Gbeassor, M. and de Souza, C. (2012). Medicinal plants use in central Togo (Africa) with an emphasis on the timing. Pharmacog. Res. 4: 92-103

40. Tittikpina, N.K., Agban, A., Gbogbo, K.A., Houkou, Y.P., Pereki, H., Batawila, K. and Akpagana, K. (2013). Évaluation des propriétés antimicrobiennes de Pterocarpus erinaceus Poir (Faboïdeae) et Daniellia oliveri (Rolfe) Hutch. et Dalz (Caesalpinoïdeae), utilisées en médecine traditionnelle au Togo. Int. J. Biol. Chem. Sci. 7: 1586-1594.

41. Tomasetti, M., Santarelli, L., Alleva, R., Dong, L-F. and Neuzil, J. (2015). Redox-active and redox-silent compounds: Synergistic therapeutics in cancer. Curr. Med. Chem. 22: 552-568

42. White, F. (1986). La végétation de l'Afrique: mémoire accompagnant la carte de végétation de l'Afrique AETFAT/UNSO

43. Xua, Z., Dua, P., Meiserb, and Jacob, C. (2012). Proanthocyanidins: Oligomeric structures with unique biochemical properties and great therapeutic promise. Nat. Prod. Comm. 7: 381-8

44. Yazdi, M.H., Mahdavi, M., Varastemoradi, B., Faramarzi, M.A. and Shahverdi, A.R. (2012). The immumostimulatory effect of biogenic selenium nanoparticles on the 4T1 breast cancer models: an in vivo study. Biol. Trace Elem. Res. 149: 22-28

45. Yazdi, M.H., Mahdavi, M., Setayesh, N., Esfandyar, M.S. and Shahverdi, A.R. (2013). Selenium nanoparticle-enriched Lactobacillus brevis causes more efficient immune responses in vivo and reduces the liver metastasis in metastatic form of mouse breast cancer. DARU J. Pharm. Sci. 21: 33

46. Zabouh, K.W. (2014). Étude des plantes médicinales utilisées en ethnomédecine vétérinaire dans la région des savanes du Lomé (Togo). Th. Doc. Pharmacie, Université de Lomé, Togo. pp 1 